\title{
THE INSULIN AND THE ZINC CONTENT OF NORMAL AND DIABETIC PANCREAS
}

\author{
By D. A. SCOTT ANd A. M. FISHER
}

(From the Connaught Laboratories, University of Toronto, Toronto, Canada)

(Received for publication June 13, 1938)

Although insulin, the antidiabetic principle of the pancreas, was discovered in 1921 (1) there is no record, so far as we are aware, of any study comparing the insulin content of the pancreas of normal individuals with that of the pancreas of persons suffering from diabetes mellitus. The reason for the lack of information on this phase of the study of diabetes is probably owing to an assumption that, since the condition of the diabetic is suggestive of a shortage of insulin, the pancreas must contain less insulin than is normally present. However, other explanations for an apparent shortage of insulin would also seem feasible. For example, it might be suggested that, in the diabetic patient, the insulin is stored in, or excreted from, the pancreas in a form which the body is not able to utilize. Again, the apparent deficiency of insulin may be due, not to any abnormality in the excretion of the hormone itself, but rather to the liberation of an excessive amount of one or more substances which modify the action of the hormone. It is known that the blod-sugar-lowering action of insulin can be greatly modified by the addition, in vitro, of various constituents of pancreas, blood, and thymus gland. Zinc, spermine (both normally present in pancreas), a preparation from blood and another from thymus gland have all been shown to prolong or even annul this action of the hormone $(2,3,4,5,6)$. On the other hand, it could be suggested that diabetes is concerned, not with an abnormal functioning of the pancreas but with a disorder in some other gland, such as a pituitary disturbance $(7,8)$. In view of the foregoing, it was a matter of interest to ascertain the insulin content of the pancreas of a series of normal and diabetic persons. Because of the close association between insulin and zinc, as shown in publications from these Laboratories $(9,10)$, it was decided to estimate the zinc content of each pancreas. Since the liver also is concerned with carbohydrate metabolism, the zinc content of this organ was likewise determined.

\section{EXPERIMENTAL}

Over a period of several months, a series of 14 pancreases was obtained at the autopsy of individuals who had met almost instantaneous death resulting from accidents or other causes. These subjects had no history of diabetes and may be taken to represent as nearly as possible a normal group of individuals. At each autopsy a sample of liver was also obtained.

Another series of 18 pancreases was obtained at autopsy of individuals who had a history of diabetes mellitus usually of some years' duration. All the patients were receiving insulin daily. The severity of the disease ranged from mild to moderately severe. Diabetes was a contributory rather than a primary cause of death. The time elapsing between death and autopsy was, as in the control group, approximately 10 hours. A sample of liver was also obtained at each autopsy. Immediately on obtaining the pancreas and liver, they were taken to the laboratory and the pancreas weighed. The zinc and the insulin content of each pancreas and the zinc content of the liver was estimated as described below.

Zinc estimations. All samples of pancreas and liver for zinc estimations were digested with $5 \mathrm{~N} \mathrm{HCl}$. A sufficient quantity of this acid was prepared, for all the analyses recorded herein, by distilling 20 per cent hydrochloric acid (C. P.) in pyrex glassware, and diluting the distillate to the desired strength with distilled water. A spectroscopic analysis of this solution gave a negative test for zinc.

The pancreas was cut into small pieces by means of stainless steel scissors. From this a 10-gram sample was weighed and transferred to a $100 \mathrm{cc}$. pyrex digestion flask. To this was added 50 cc. of the acid digestion liquid. This mixture was refluxed for 1 hour and was then allowed to stand overnight. The following morning the volume was measured and the mixture filtered through acid-washed filter paper. The zinc content of an aliquot of the filtrate was estimated spectroscopically and the amount of zinc per gram of tissue calculated. The zinc content per gram of liver was calculated from a similar digestion carried out on $\mathbf{1 0}$ grams of liver with 50 cc. of the acid digestion mixture. The results of these estimations are shown in Tables I and II.

The spectroscopic analyses were conducted by Dr. S. Bateson of the Department of Physics of this Uni- 
versity. Details of the method, limit of error \pm 3 per cent, will be published elsewhere.

Insulin estimations. Immediately after removal of the 10-gram sample of pancreas for the zinc estimation, the remainder was minced. The material was then weighed into an Erlenmeyer flask and to it was added acid alcohol in the proportion of $2.5 \mathrm{cc}$. for each gram of pancreas. (Several liters of the alcoholic extraction fluid were prepared and portions of it used for extracting each pancreas. It consisted of $750 \mathrm{cc}$. of absolute alcohol, $15 \mathrm{cc}$. of concentrated hydrochloric acid, and $235 \mathrm{cc}$. of water.) After standing overnight the mixture was filtered through a double layer of cheese-cloth and pressed until nearly dry. The solid material was again extracted for two hours with a volume of acid alcohol equal to that used in the first extraction. The alcoholic extract was again filtered through cheese-cloth and the two extracts combined. The filtrate was made slightly ammoniacal and the volume measured. The mixture was filtered through filter paper and four $10 \mathrm{cc}$. quantities pipetted into each of four $50 \mathrm{cc}$. centrifuge thimbles. To each tube were now added $15 \mathrm{cc}$. of absolute alcohol and $25 \mathrm{cc}$. of ether. The mixtures were shaken and placed in the refrigerator overnight. They were then centrifuged, the supernatant ether-alcohol discarded, and the tubes allowed to drain for one-half hour. The precipitate in each tube was then dissolved in $10 \mathrm{cc}$. of isotonic saline $(\mathrm{pH} \mathrm{2.5)}$. The insulin in these solutions or of further dilutions of them was estimated by the mouse method of assay (11). Generally, six tests were conducted involving at least 300 mice. From the average of these potency values the number of units of insulin per gram of pancreas was calculated. The limit of error in the assays was probably not greater than 10 per cent. The insulin content of each pancreas is recorded in Tables I and II.

TABLE I

The insulin and the zinc content of the pancreas of non-diabetics

\begin{tabular}{|c|c|c|c|c|c|c|c|c|c|c|}
\hline $\begin{array}{c}\text { Pa- } \\
\text { tient } \\
\text { num- } \\
\text { ber }\end{array}$ & Sex & Age & $\begin{array}{c}\text { Cause of } \\
\text { death }\end{array}$ & $\begin{array}{c}\text { Time } \\
\text { elapsing } \\
\text { between } \\
\text { death } \\
\text { and } \\
\text { autopsy }\end{array}$ & $\begin{array}{l}\text { Weight } \\
\text { of } \\
\text { pan- } \\
\text { oreas }\end{array}$ & $\begin{array}{c}\text { In- } \\
\text { sulin } \\
\text { per } \\
\text { gram } \\
\text { of } \\
\text { pan- } \\
\text { creas }\end{array}$ & $\begin{array}{l}\text { Total } \\
\text { in- } \\
\text { sulin } \\
\text { per } \\
\text { pan- } \\
\text { creas }\end{array}$ & $\begin{array}{l}\text { Zino } \\
\text { per } \\
\text { gram } \\
\text { of } \\
\text { pan- } \\
\text { oreas }\end{array}$ & $\begin{array}{l}\text { Total } \\
\text { sino } \\
\text { per } \\
\text { pan- } \\
\text { creas }\end{array}$ & $\begin{array}{l}\text { Zino } \\
\text { per } \\
\text { gram } \\
\text { of } \\
\text { liver }\end{array}$ \\
\hline & & years & & hours & grams & units & units & mom. & mgm. & mom. \\
\hline 1 & M. & 12 & Auto & 10 & 44 & 2.1 & 92 & 0.18 & 7.9 & 0.25 \\
\hline 2 & M. & 14 & Auto & 9 & 116 & 1.9 & 220 & 0.13 & 15.1 & 0.22 \\
\hline $\begin{array}{l}3 \\
4\end{array}$ & $\begin{array}{l}\text { M. } \\
\text { F. }\end{array}$ & $\begin{array}{l}15 \\
19\end{array}$ & $\begin{array}{l}\text { Drowned } \\
\text { Auto }\end{array}$ & $\begin{array}{l}12 \\
10\end{array}$ & $\begin{array}{l}40 \\
68\end{array}$ & $\begin{array}{l}2.5 \\
1.8\end{array}$ & $\begin{array}{l}100 \\
122\end{array}$ & $\begin{array}{l}0.13 \\
0.13\end{array}$ & $\begin{array}{l}5.2 \\
8.8\end{array}$ & $\begin{array}{l}0.25 \\
0.25\end{array}$ \\
\hline 5 & M. & 33 & Auto & 10 & 97 & 1.4 & 136 & 0.12 & 11.6 & 0.16 \\
\hline 6 & F. & 35 & Street car & 12 & 120 & 1.0 & 120 & 0.09 & 10.8 & 0.26 \\
\hline 7 & M. & 38 & Fractured & 12 & 74 & 3.8 & 279 & 0.15 & 11.1 & 0.19 \\
\hline 8 & M. & 47 & Alcoholio & 10 & 248 & 0.6 & 149 & 0.20 & 59.6 & 0.18 \\
\hline 0 & M. & 52 & Alcoholio & 5 & 150 & 1.4 & 210 & 0.18 & 27.0 & 0.25 \\
\hline $\begin{array}{l}10 \\
11\end{array}$ & $\begin{array}{l}\text { M. } \\
\text { M. }\end{array}$ & $\begin{array}{l}55 \\
56\end{array}$ & $\begin{array}{l}\text { poisoning } \\
\text { Suicide } \\
\text { Fractured }\end{array}$ & $\begin{array}{l}4 \\
8\end{array}$ & $\begin{array}{l}115 \\
115\end{array}$ & $\begin{array}{l}2.6 \\
2.0\end{array}$ & $\begin{array}{l}299 \\
230\end{array}$ & $\begin{array}{l}0.14 \\
0.24\end{array}$ & $\begin{array}{l}16.1 \\
27.6\end{array}$ & $\begin{array}{l}0.30 \\
0.26\end{array}$ \\
\hline 12 & M. & 60 & Auto & 11 & 125 & 1.1 & 137 & 0.10 & 13.8 & 0.24 \\
\hline 13 & M. & 72 & Struck by & 12 & 263 & 0.8 & 210 & 0.11 & 28.9 & 0.15 \\
\hline 14 & M. & 75 & $\begin{array}{l}\text { Coronary } \\
\text { thrombogis }\end{array}$ & 10 & 101 & 1.2 & 121 & 0.10 & 10.1 & 0.16 \\
\hline \multicolumn{2}{|c|}{$\overline{\text { Average }}$} & 41.2 & & 9.6 & 119.7 & 1.7 & 173 & 0.14 & 18.1 & 0.22 \\
\hline
\end{tabular}

TABLE II

The insulin and the zinc content of the pancreas of diabetics

\begin{tabular}{|c|c|c|c|c|c|c|c|c|c|c|c|}
\hline $\begin{array}{c}\mathrm{Pa}- \\
\text { tient } \\
\text { num- } \\
\text { ber }\end{array}$ & Sex & Age & $\begin{array}{c}\text { Complications } \\
\text { other than } \\
\text { diabetes }\end{array}$ & $\begin{array}{c}\text { Dura- } \\
\text { tion } \\
\text { of } \\
\text { dia- } \\
\text { betes }\end{array}$ & $\begin{array}{l}\text { Weight } \\
\text { of pan- } \\
\text { creas }\end{array}$ & $\begin{array}{c}\text { Insulin } \\
\text { per } \\
\text { gram } \\
\text { of pan- } \\
\text { creas }\end{array}$ & $\begin{array}{c}\text { Total } \\
\text { insulin } \\
\text { per } \\
\text { pan- } \\
\text { creas }\end{array}$ & $\begin{array}{c}\text { Zinc } \\
\text { per } \\
\text { gram } \\
\text { of pan- } \\
\text { creas }\end{array}$ & $\begin{array}{c}\text { Total } \\
\text { zinc } \\
\text { per } \\
\text { pan- } \\
\text { creas }\end{array}$ & $\begin{array}{c}\text { Zinc } \\
\text { per } \\
\text { gram } \\
\text { of } \\
\text { liver }\end{array}$ & Remarks \\
\hline $\begin{array}{l}15 \\
16 \\
17 \\
18 \\
19 \\
20 \\
21 \\
22 \\
23 \\
24 \\
25 \\
26 \\
27 \\
28 \\
29 \\
30 \\
31 \\
32\end{array}$ & $\begin{array}{l}\text { F. } \\
\text { M. } \\
\text { M. } \\
\text { M. } \\
\text { F. } \\
\text { M. } \\
\text { M. } \\
\text { F. } \\
\text { M. } \\
\text { F. } \\
\text { F. } \\
\text { F. } \\
\text { M. } \\
\text { F. } \\
\text { F. }\end{array}$ & \begin{tabular}{|c|} 
years \\
12 \\
19 \\
28 \\
44 \\
46 \\
55 \\
56 \\
56 \\
61 \\
62 \\
63 \\
63 \\
63 \\
65 \\
71 \\
72 \\
74 \\
76
\end{tabular} & $\begin{array}{l}\text { Anuria } \\
\text { Pneumonia } \\
\text { Tuberculosis } \\
\text { Septicemia } \\
\text { Hyperthyroidism } \\
\text { Pneumonia } \\
\text { Hypertension } \\
\text { Coronary thrombosis } \\
\text { Adrenal tumor } \\
\text { Septicemia } \\
\text { Carcinoma } \\
\text { Carcinoma } \\
\text { Arteriosclerosis } \\
\text { Arteriosclerosis } \\
\text { Auricular fibrillation } \\
\text { Chronic myocarditis } \\
\text { Arteriosclerosis }\end{array}$ & $\begin{array}{r}\text { years } \\
7 \\
1 \\
10 \\
5 \\
10 \\
1 \\
5 \\
7 \\
16 \\
8 \\
8 \\
3 \\
4 \\
12 \\
12 \\
8 \\
8\end{array}$ & \begin{tabular}{|r|} 
grams \\
41 \\
94 \\
70 \\
64 \\
130 \\
86 \\
65 \\
75 \\
149 \\
85 \\
120 \\
190 \\
70 \\
95 \\
80 \\
120 \\
110 \\
85
\end{tabular} & \begin{tabular}{|c|} 
units \\
$<0.08$ \\
0.1 \\
$<0.03$ \\
0.3 \\
\\
0.3 \\
0.7 \\
0.5 \\
0.5 \\
0.4 \\
0.8 \\
0.1 \\
0.3 \\
0.5 \\
0.2 \\
0.2 \\
1.9
\end{tabular} & $\begin{array}{r}\text { units } \\
<3 \\
10 \\
<3 \\
19 \\
\\
26 \\
45 \\
38 \\
75 \\
34 \\
96 \\
19 \\
28 \\
40 \\
26 \\
26 \\
162\end{array}$ & $\begin{array}{c}\text { mgm. } \\
0.07 \\
0.09 \\
0.09 \\
0.09 \\
0.06 \\
0.10 \\
0.06 \\
0.05 \\
0.05 \\
0.08 \\
0.04 \\
0.05 \\
0.10 \\
0.07 \\
0.08 \\
0.04 \\
0.11 \\
0.04\end{array}$ & $\begin{array}{r}m g m . \\
2.9 \\
8.5 \\
6.3 \\
5.8 \\
7.8 \\
8.6 \\
3.9 \\
3.7 \\
7.5 \\
6.8 \\
4.8 \\
9.5 \\
7.0 \\
6.7 \\
6.4 \\
4.8 \\
12.1 \\
3.4\end{array}$ & $\begin{array}{l}0.15 \\
0.09 \\
0.14 \\
0.16 \\
0.17 \\
0.20 \\
0.22 \\
0.14 \\
0.29 \\
0.19\end{array}$ & $\begin{array}{l}\text { Severe diabetic } \\
\text { Mild diabetic; fatty pancreas } \\
\text { Moderately severe diabetic } \\
\text { Pancreas preserved in formalin } \\
\text { Mild diabetic } \\
\text { Mild diabetic } \\
\text { Mild diabetic } \\
\text { Mild diabetic; fatty pancreas } \\
\text { Mild diabetic } \\
\text { Fatty pancreas } \\
\text { Pancreas preserved in formalin } \\
\text { Mild diabetic } \\
\text { Mild diabetic } \\
\text { Moderately severe diabetic } \\
\text { Moderately severe diabetic }\end{array}$ \\
\hline \multicolumn{2}{|c|}{ Average } & 55 & & 7 & 96 & $<0.4$ & $<40$ & 0.07 & 6.5 & 0.18 & \\
\hline
\end{tabular}




\section{DISCUSSION}

It will be seen from Table I that the average value obtained for the insulin content of the pancreas of normal individuals is 1.7 international units per gram. This value is in good agreement with that obtained in previous work (12) in which it was shown that the insulin content of the pancreas of mature cows is about 1.8 international units per gram. Similarly, it has recently been found that, in cats, the insulin content of the pancreas is approximately 1.7 international units per gram. It would appear that the insulin content of the pancreas of normal humans is unaffected by age, provided the individuals are at least 12 years old. Such a result was not anticipated in view of a previous paper (12) showing that the insulin content of the pancreas of young calves is much greater than that of two-year old cattle. However, it may be that an investigation of the insulin content of the pancreas during infancy or early childhood would show that such pancreases contain much more insulin than was found in the series reported in the present paper. It will be noted that two pancreases in this group (Patients 8 and 13) have less than one unit of insulin per gram of tissue. These pancreases were fatty and were much heavier than the average normal pancreas. Their total insulin content compares favorably with that found in the remaining pancreases in this group. The zinc content per gram of tissue was found to be less in the pancreas than in the liver. In normal cats, on the other hand, it has been found that the zinc content per gram of tissue is less in the liver than in the pancreas (13). However, in both cats and humans the total zinc content of the liver is many times that of the pancreas.

In Table II it is shown that the average value for the insulin content of the pancreas of diabetics is less than 0.4 unit of insulin per gram of tissue. Thus these glands contain less than one quarter the amount of insulin found in those of the normal group. It will also be noted from Table II that there is a great variation in the concentration of insulin in the various pancreases. Most of the pancreases contain between 0.1 and 0.5 unit of insulin per gram of tissue. There are two (Patients 15 and 17) having less than
0.1 , and three (Patients 21, 24, and 32) with more than 0.5 unit of insulin per gram of pancreas. It is surprising that the very low values occurred in the younger age group since we have shown that, in cattle, the lower values occur in the older age groups. Patient 15 was admitted to the hospital in diabetic coma. During the 36hour interval before death she received 200 units of insulin with no clinical response. Patient 17, although only a mild diabetic, had been extremely difficult to keep under proper control. During the 24 hours prior to death this patient received 104 units of insulin. From the insulin determinations it is evident that the injected insulin was not stored in the pancreas in either case. Of the three patients having an insulin content of more than 0.5 unit of insulin per cc., Patient 32 is the most interesting and surprising. This patient had been a moderately severe diabetic for many years but was kept under fairly good control with insulin. Death was caused by extreme arteriosclerosis showing fibrosis of the myocardium and acute aortitis. The pancreas was fibrous and showed marked arteriosclerosis. Whether any of these complications is responsible for the extremely high insulin content of this pancreas is, in our opinion, doubtful. At the present time we are quite unable to give any valid reasons for this diabetic having a pancreas with a normal insulin content. The average zinc content of the diabetic pancreases is one-half the value obtained for the normal pancreases. The concentration of zinc in the liver is only slightly less in the diabetic group than in the control group. This is probably insignificant since the liver of many diabetics is enlarged and often contains a relatively large amount of fat. Hence the total zinc content of such livers might equal, or even exceed, that of the livers of normal individuals.

\section{SUM MARY}

Fourteen normal and eighteen diabetic pancreases were obtained at autopsy and the insulin and zinc content of each of these determined. In the pancreas of diabetics, the total amount of insulin present amounts to only one-quarter that found in the pancreas of normal individuals. Likewise, the amount of zinc contained in the pancreas of diabetics is only one-half that nor- 
mally present. There is no marked difference in the zinc concentration in livers of diabetics and non-diabetics. Certain abnormally high and low insulin values found amongst the diabetic pancreases are discussed. The possibility of a part of the zinc in the pancreas being concerned with the storage of insulin is suggested.

\section{BIBLIOGRAPHY}

1. Banting, F. G. and Best, C. H., The internal secretions of the pancreas. J. Lab. and Clin. Med., 1921, 7, 251.

2. Scott, D. A. and Fisher, A. M., The effect of zinc salts on the action of insulin. J. Pharmacol. and Exper. Therap., 1935, 55, 206.

3. Scott, D. A. and Fisher, A. M., The prolongation of insulin action by protamine and zinc. J. Biol. Chem. (Proc.), 1936, 114, 1xxxviii.

4. Fisher, A. M. and Scott, D. A., Spermine, zinc and insulin. J. Pharmacol. and Exper. Therap., 1937, 61, 21.
5. Fisher, A. M. and Scott, D. A., The effect of various substances on the action of insulin. J. Pharmacol. and Exper. Therap., 1936, 58, 93.

6. Bischoff, F. and Maxwell, L. C., Influence of delayed resorption of the protein hormones. J. Biol. Chem. (Proc.), 1936, 114, xi.

7. Houssay, B. A., Diabetes as a disturbance of endocrine regulation. Am. J. M. Sc., 1937, 193, 581.

8. Young, F. G., Permanent experimental diabetes produced by pituitary (anterior lobe) injections. Lancet, 1937, 2, 372.

9. Scott, D. A., Crystalline insulin. Biochem. J., 1934, 28, 1592.

10. Scott, D. A. and Fisher, A. M., Crystalline insulin. Biochem. J., 1935, 29, 1048.

11. Scott, D. A., The assay of the international crystalline insulin standard by the mouse method. Quart. Bull. Health Organ., League of Nations, 1936, 5, 607.

12. Fisher, A. M. and Scott, D. A., The insulin content of the pancreas in cattle of various ages. J. Biol. Chem., 1934, 106, 305.

13. Scott, D. A., and Fisher, A. M., Studies on the pancreas and liver of normal and of zinc-fed cats. Am. J. Physiol., 1938, 121, 253. 